E-ISSN. 2685-7650

Vol. 2 No. 1 (2020), pp 28-41

DOI: https://doi.org/10.33366/jkn.v2i1.38

\title{
Integrasi Orkestrasi Pemasaran dengan Filosofi Dwi Sapta pada Kasus Vaseline Healing Project
}

\author{
Bella Laurensia ${ }^{1}$, Hot Junita Sitanggang ${ }^{2}$, Rustono Farady Marta ${ }^{3}$, Agus Daniar ${ }^{4}$, \\ Alfred Pieter Menayang 5 \\ ${ }^{1,2}$ Program Studi Ilmu Komunikasi, Universitas Bunda Mulia \\ 3,4,5 Program Studi Margister Ilmu Komunikasi, Universitas Bunda Mulia \\ Email: rmarta@bundamulia.ac.id
}

\begin{abstract}
Integrated Marketing Communication as a form of marketing communication strategy in order to build trust, maintain relationships with consumers and stakeholders and benefit the brand. This study aims to determine the application of marketing orchestration in Vaseline activities and the application of the Dwi Sapta Philosophy in Vaseline marketing communication. This type of research is descriptive qualitative using the case study method. Vaseline held a "Vaseline Healing Project" to improve the quality of life of people and provide skin care to the community. Vaseline consistently provides the best for its consumers, ranging from product variations, product quality to the services provided through training of medical personnel and also the mission of improving the skin condition of the community.
\end{abstract}

Keywords: Integrated Marketing Communication, Vaseline, Dwi Sapta Philosophy, Orchestration, Case Study

\begin{abstract}
Abstrak: Integrated Marketing Communication sebagai bentuk strategi komunikasi pemasaran guna untuk membangun kepercayaan, memelihara hubungan dengan konsumen dan stakeholder serta menguntungkan brand. Penelitian ini bertujuan untuk mengetahui mengetahui penerapan orkestrasi pemasaran dalam aktivitas Vaseline dan penerapan Filosofi Dwi Sapta di dalam komunikasi pemasaran Vaseline. Jenis penelitian ini adalah deskriptif kualitatif dengan menggunakan metode studi kasus. Vaseline mengadakan "Vaseline Healing Project" untuk memperbaiki kualitas hidup masyarakat dan memberikan perawatan kulit pada masyarakat. Vaseline secara konsisten memberikan yang terbaik untuk konsumennya, mulai dari variasi produk, kualitas produk hingga pelayanan yang diberikan melalui pelatihan tenaga medis dan juga misi memperbaiki kondisi kulit masyarakat.
\end{abstract}

Kata kunci: Integrated Marketing Communication, Vaseline, Filosofi Dwi Sapta, Orchestration, Studi Kasus

\section{Pendahuluan}

Bisnis merupakan suatu kegiatan yang sudah dijalankan sejak ratusan tahun lalu. Berbagai jenis bisnis yang ada hingga saat ini juga sangat beragam seiring dengan perkembangan jaman. Apabila kita lihat lingkup bisnis tidak harus terkait dengan produk, namun penyediaan jasa pun bisa dikategorikan sebagai bisnis (Hardhiyanti \& Rasyid, 2017). Menurunnya pendapatan perusahaan yang disebabkan oleh minat konsumen terhadap suatu jasa, mengakibatkan lambatnya pertumbuhan dan perkembangan perusahaan atau instansi. Maka dari itu diperlukannya berbagai kegiatan komunikasi pemasaran yang mendukung terciptanya pertumbuhan perusahaan. Startegi pemasaran yang efektif dan efisien mendukung terciptanya jalinan komunikasi dan relasi yang baik antara perusahaan dan konsumennya (Yulius \& Prasetya Widodo, 2019).

Komunikasi adalah penyampaian informasi dan pengertian dari satu orang ke orang lain. Komunikasi akan dapat bekerja dengan baik ketika acara datang saling pengertian, yaitu, jika kedua pihak, pengirim dan penerima dapat memahami informasi. Proses informasi yang baik 


\section{Jurnal Komunikasi Nusantara}

\section{E-ISSN. 2685-7650}

Vol. 2 No. 1 (2020), pp 28-41

DOI: https://doi.org/10.33366/jkn.v2i1.38

hanya akan terjadi ketika yang menyampaikan informasi mengerti posisi atau sudut pandang penerima informasi (Mahayoni, 2015). Komunikasi dalam kegiatan pemasaran bersifat kompleks, artinya tidak sesederhana seperti ketika kita berbincang-bincang dengan rekan sekantor, atau dengan keluarga di rumah (Sampurna et al., 2020). Dasar pengetahuan yang harus dimiliki adalah pengetahuan mengenai komunikasi dua arah atau hubungan timbal balik. Komunikasi dua arah terbagi dalam dua jenis, yaitu two-way asymmetrical communication (komunikasi dua arah asimetris) dan two-way symmetrical communication (komunikasi dua arah simetris). Perbedaan dari kedua model tersebut terletak pada tujuannya. Jika pada asymmetrical hanya mempengaruhi publik sesuai dengan keinginan organisasi, pada symmetrical terjadi proses saling mendengarkan dan merespon keinginan stakeholder-nya. Tentunya kedua model tersebut digunakan secara situasional (Saputra \& Marta, 2020).

Komunikasi pemasaran adalah upaya perusahaan untuk menyampaikan informasi kepada publik terutama konsumen mengenai produk atau jasa yang ditawarkan. Komunikasi pemasaran berperan dalam membangun citra (image) suatu perusahaan. Selain itu komunikasi pemasaran dapat membentuk kesadaran konsumen terhadap produk atau jasa yang ada di suatu perusahaan, sehingga konsumen lebih mengenal produk atau jasa tersebut (Rambu Babang \& Rachmad Rinata, 2019).

Komunikasi pemasaran terpadu atau kini lebih dikenal dengan sebutan Integrated Marketing Communication (IMC) adalah sebuah konsep dimana suatu perusahaan mengintegrasikan dan mengkoordinasikan berbagai saluran komunikasi untuk mengirim pesan yang jelas, konsisten, dan meyakinkan berkenaan dengan perusahaan dan produknya (Ulfa \& Marta, 2016).

Menurut Tom Duncan, perusahaan harus mulai beralih dari menggunakan pemikiran dalam ke luar menjadi luar ke dalam. Pemikiran dari luar dimulai dari pelanggan dam berfokus pada kebutuhan dan keinginan pelanggan. Mulanya komunikasi pemasaran berfokus pada $4 \mathrm{P}$ (Product, Place, Price dan Promotion), kini berubah menjadi 4C. 4C terdiri dari: (1) Customer, fokus pada kebutuhan dan keinginan pelanggan, bukan hanya produk, ini membuat komunikasi lebih berdasarkan hubungan. (2) Cost, berfokus pada biaya pelanggan untuk memiliki atau menggunakan produk atau layanan alih-alih memberi harga pada produk untuk mendapat untung. Konsep ini membuat organisasipertimbangkan berapa biaya suatu produk dalam jangka panjang, termasuk faktor-faktor seperti biaya perawatan. (3) Convenience, fokus pada betapa mudahnya bagi pelanggan untuk mendapatkan atau membeli produk alih-alih betapa mudahnya bagi perusahaan untuk mendistribusikan produk. Dengan meningkatnya penggunaan internet dan pesanan telepon, konsumen tidak perluuntuk meninggalkan rumah mereka untuk membeli itulah sebabnya hal-hal seperti e-commerce miliki sudah begitu sukses. (4) Communication, berfokus pada komunikasi dua arah dengan konsumen -"Mendengarkan dan belajar" alih-alih komunikasi satu arah "mengatakan dan menjual". Ini adalah perubahan terakhir dan paling penting bagi organisasi dan pemasaran mereka strategi. Promosi tradisional termasuk mengirim pesan merek ke konsumen meminta mereka untuk membeli dan jika mereka bisa menghubungkannya dengan pesan itumereka membeli. Fokusnya adalah membangun hubungan yang lebih kuat komunikasi (Smith, 2003).

Menurut Duncan, gagasan dasar tentang IMC adalah hubungan yang menguntungkan, memperluas ruang lingkup khalayak dari konsumen (customers) ke arah stakeholders (Estaswara, 2008). Integrated Marketing Communication (IMC) merupakan strategi komunikasi yang memaksimalkan pesan positif dan meminimalisir pesan negatif dari suatu brand atau perusahaan dengan menciptakan hubungan jangka panjang dengan konsumen sehingga mendatangkan keuntungan dan meningkatkan nilai dari perusahaan atau brand tersebut. Integrated Marketing Communication (IMC) sebagai kumpulan berbagai pesan yang telah 


\section{Jurnal Komunikasi Nusantara}

\section{E-ISSN. 2685-7650}

Vol. 2 No. 1 (2020), pp 28-41

DOI: https://doi.org/10.33366/jkn.v2i1.38

dirancang untuk membangun suatu brand antara lain iklan, pemasaran langsung, internet marketing, promosi penjualan, publisitas dan penjualan secara individu. Integrated Marketing Communication (IMC) merupakan proses pemeliharaan hubungan antara konsumen dan stakeholder melalui pesan yang disampaikan sehingga menciptakan brand relationship yang positif dan menguntungkan bagi brand atau perusahaan tersebut. Menurut Holm dengan mengutip Duncan (2002), berbagai hambatan dalam membangun IMC dari sekadar taktik menuju pada sebuah strategi, dapat diselesaikan jika kita menerima dan mengakui bahwa komunikasi adalah fondasi utama dari keseluruhan interaksi manusia. Di samping itu, ia menambahkan, kita juga harus menerima bahwa hanya dengan orientasi yang strategis terhadap komunikasi merek yang terintergrasi akan membuat perusahaan semakin kompetitif (Estaswara, 2008).

Dengan perubahan budaya konsumen pengguna teknologi yang signifikan, industri harus memanfaatkan keadaan dengan baik, yakni melakukan promosi dengan strategi digital marketing communication agar dapat menarik minat pelanggan melalui jejaring internet dan kemajuan teknologi.Saat ini bahkan perusahaan yang bersifat tradisional pun mulai beralih ke pemasaran digital guna mempertahankan daya saing dengan perusahaan yang lebih modern. Digital marketing communication dapat menghubungkan dengan pelanggan dari seluruh penjuru dunia. Lingkup yang sangat luas menjadikan digital marketing communication ini sebagai kegiatan promosi yang efisien karena sekaligus dapat merambah pasar secara global tanpa dibatasi oleh waktu maupun geografis (Teguh \& Ciawati, 2020).

Strategi komunikasi pemasaran yang cenderung agresif menjadi pemicu efektif dalam menciptakan citra merek yang populer bagi masyarakat (Fensi \& Christian, 2018). Strategi komunikasi memiliki beberapa tujuan, yaitu (1) Untuk memastikan bahwa terjadi suatu pengertian dalam berkomunikasi (to secure understanding). (2) Bagaimana cara penerimaan itu terus dibina dengan baik (to establish acceptance). (3) Penggiatan untuk memotivasi (to motive action). (4) Bagaimana mencapai tujuan yang hendak dicapai oleh pihak komunikator dari proses komunikasi tersebut (the goals which the communicator bought to achieve) (Tarsani, 2016).

Orkestrasi dalam konteks musik berarti mengatur atau mengubah musik untuk dimainkan oleh orkestra dalam urutan yang telah ditentukan. Penafsiran lain dari kata orkestrasi melibatkan pengorganisasian suatu peristiwa untuk mencapai hasil yang diinginkan, yang telah ditentukan sebelumnya. Hal ini mengartikan bahwa orkestrasi adalah ada hasil yang direncanakan. Orkestrasi pemasatan terbagi menjadi tujuh medote yaitu (1) Satu dirijen, kategori produk. (2) Harmonisasi, tujuan dan strategi pemasaran tidak bertentangan dengan visi dan misi. (3) Tematik, tema tertentu dalam periode tertentu. (4) Berirama, kegiatan yang beralur. (4) Spesifik, segmen khalayak yang dituju. (6) Keterpaduan, penjadwalan promosi maupun kampanye agar tidak berbenturan. (7) Apresiasi, program customer rewards sebagai bentuk penghargaan atas loyalitas (Turnbull, 2019).

Orkestrasi menggunakan berbagai platform dan saluran untuk memusatkan perhatian pada objek yang konsisten dan gigih dalam pesan. Orkestrasi mengacu pada upaya untuk mencapai kesuksesan dengan menemukan dan mengelola kombinasi kreatif untuk nilai; itu adalah kunci untuk melaksanakan manajemen hubungan baik cara lama maupun baru dalam menyelesaikan sesuatu (Catherine et al., 2020).

Filosofi Dwi Sapta memiliki lima nilai utama (core values) yaitu (1) Client Success is Our Success, (2) Commitment for Excellence, (3) Serve with the Heart, (4) Care to Our People dan (5) Give to Society. Kelima nilai utama ini menjadi pedoman dan komitmen bagi perusahaan. Tentunya filosofi ini harus diimbangi dengan pikiran, sikap dan juga tindakan agar terbentuk, terbiasa dan menjadi karakter serta budaya perusahaan. Inti dari kelima nilai utama 


\section{Jurnal Komunikasi Nusantara}

\section{E-ISSN. 2685-7650}

Vol. 2 No. 1 (2020), pp 28-41

DOI: https://doi.org/10.33366/jkn.v2i1.38

tersebut adalah Do the Best for Everybody (Care-Share-Love). Bahwa perusahaan harus bersungguh-sungguh melakukan yang terbaik kepada seluruh stakeholder dan audiencenya. Usaha dan kerja keras memberikan hasil yang terbaik karena terdapat totalitas dan kesungguhan di dalamnya. Dalam menjalankan "Do the Best for Everybody" tersebut dibagi ke dalam tiga tahapan yaitu: (1) Do the Best for Client, perusahaan berfokus untuk memberikan yang terbaik bagi audiencenya. Mulai dari kualitas produk, konsistensi kualitas produk dan layanan yang diberikan. Audience merupakan hal yang utama bagi perusahaan, perusahaan berusaha untuk memenuhi setiap kebutuhan dan keinginan dari audiencenya dan audience memberikan loyalitasnya kepada perusahaan serta rewards untuk audience. (2) Do the Best for Our People, perusahaan memberikan yang terbaik bukan hanya untuk audeiencenya tetapi juga kepada stakeholdernya yang diwujudkan melalui kegiatan gathering perusahaan atau rewards kepada karyawan teladan dan berprestasi. (3) Do the Best for Society, perusahaan peduli terhadap masyarakat yang ada di sekitar mereka. Hal ini diwujudkan melalui kegiatan Corporate Social Responsibility (CSR) yang diadakan oleh perusahaan (A. Adji Watono, 2011)

Unilever didirikan pada 5 Desember 1933 dengan nama Lever's Zeepfabrieken N.V. yang berlokasi di daerah Angke, Jakarta Utara. Pada 22 Juli 1980, nama perusahaan berganti menjadi PT Unilever Indonesia dan pada 30 Juni 1990, nama perusahaan berganti lagi menjadi PT Unilever Indonesia Tbk. Unilever Indonesia merupakan salah satu perusahaan Home and Personal Care ternama di Indonesia (Unilever, 2020a).

Unilever memiliki budaya organisasi yang ditetapkan oleh perusahaan setiap berhubungan dengan mitra kerja sama, masyarakat maupun lingkungan sekitar. Unilever selalu menerapkan integritas dan rasa hormat kepada semua mitra kerja sama dan terlibat dalam bisnis, menyalurkan dampak positif kepada masyarakat melalui brand dan acara-acara yang diselenggarakan, merencanakan tujuan untuk kesuksesan di masa mendatang dan bermitra dengan pemasok yang memiliki prinsip yang sejalan dengan budaya organisasi yang dipegang oleh Unilever.

Unilever memiliki tujuan mulia yaitu memasyarakatkan kehidupan yang berkelanjutan. Setiap ikon pada logo mewakili suatu aspek dari setiap upaya serta tujuan Unilever. Beberapa elemen ikonnya terdiri dari rambut (kecantikan dan tampil menarik), bibir (simbol komunikasi, transparansi dan keterbukaan), putaran (gairah terhadap rasa dan cita rasa yang luar biasa), ikan (makanan segar dan sumber daya alam), pakaian (cucian segar dan penampilan menarik), lebah (semangat komunitas), DNA (warisan positif Unilever), tumbuhan (mengurangi dampak lingkungan di seluruh rantai bisnis Unilever), hati (cinta, kepedulian dan kesehatan).

Strategi dari Unilever adalah menjadikan kehidupan berkelanjutan yang lumrah serta mengimplementasikan visi yang menciptakan kemajuan yang memberi keuntungan bagi semua pemangku kepentingan. Visi dari Unilever adalah mengembangkan bisnis, meningkatkan kesehatan dan kesejahteraan, meningkatkan penghidupan, dan mengurangi dampak lingkungan.

Vaseline pertama kali didirikan oleh Robert Chesebrough pada tahun 1870. Vaseline memulai misinya untuk membantu memperbaiki kulit kering seluruh masyarakat Amerika. Vaseline percaya bahwa kulit yang benar-benar sehat dimulai dengan mengembalikan kelembapan kulit secara mendalam. Kulit yang benar-benar sehat bukanlah hal yang bisa Anda dapatkan dengan menutupi masalah atau melalui perbaikan instan. Kami mengerti hal ini karena kami adalah ahli kulit yang sesungguhnya. Sembari melanjutkan inovasi dan mengembangkan produk-produk baru, kami tidak akan melupakan tekad dan hasratnya untuk memahami kulit (Vaseline, 2020).

Rumusan masalah penelitian ini adalah (1) Bagaimana Vaseline menerapkan orkestrasi pemasaran dalam aktivitas brandnya? (2) Bagaimana Filosofi Dwi Sapta diterapkan dalam komunikasi pemasaran Vaseline? Sedangkan tujuan penelitiannya adalah (1) Untuk mengetahui 


\section{Jurnal Komunikasi Nusantara}

\section{E-ISSN. 2685-7650}

Vol. 2 No. 1 (2020), pp 28-41

DOI: https://doi.org/10.33366/jkn.v2i1.38

penerapan orkestrasi pemasaran dalam aktivitas Vaseline. (2) Untuk mengetahui penerapan Filosofi Dwi Sapta di dalam komunikasi pemasaran Vaseline.

\section{Metode Penelitian}

Metode adalah cara, pendekatan, atau proses untuk menyampaikan informasi. Penelitian adalah suatu cara untuk meningkatkan, memodifikasi, dan mengembangkan pengetahuan yang dapat disampaikan atau juga dikomunikasikan, yang kemudian akan diuji oleh peneliti lain (Prasetya et al., 2020).

Jenis penelitian ini adalah deskriptif kualitatif, yaitu jenis penelitian yang dimana data yang diperoleh diuraikan dengan jelas dan rinci. Penelitian kualitatif adalah penelitian yang dilakukan dengan memahami fenomena yang terjadi di sekitar dengan meneliti pengaruh sosial yang tidak bisa diuji melalui penelitian kuantitatif. Jenis penelitian deskripsi kualitatif digunakan untuk mengkaji kejadian atau fenomena.

Mulyana menyatakan bahwa studi sebagai suatu metode kualitatif, mempunyai beberapa keuntungan, yaitu: (1) Merupakan sasaran utama bagi penelitian empirik, yakni menyajikan pandangan subjek yang diteliti, (2) Menyajikan uraian menyeluruh mirip dengan apa yang dialami pembaca dalam kehidupan sehari-hari, (3) Merupakan sarana efektif untuk menunjukan hubungan antara peneliti dengan narasumber, (4) Memungkinkan pembaca menemukan konsistensi internal yang terpercaya, (5) Memberikan uraian tebal yang diperlukan bagi penilaian atau transerabilitas, (6) Terbuka bagi penelitian atas kontteks yang turut berperan bagi pemaknaan atas fenomena dalam konteks tersebut (Nurhadi, 2015).

Metode penelitian yang digunakan adalah studi kasus. Studi kasus adalah suatu penelitian yang dilakukan secara intensif, terinci dan mendalam terhadap suatu organisasi, lembaga atau gejala tertentu. Menurut Mulyana, studi kasus adalah uraian dan penjelasan komprehensif mengenai berbagai aspek seorang individu, suatu kelompok masyarakat (Sapoetri \& Pannindriya, 2019). Studi kasus merupakan metode yang terdapat dalam kelompok analisis kerja dan pengalaman individual serta perilaku institusi. Metode ini juga merupakan salah satu strategi yang menekankan pada kasus-kasus khusus (Saputra \& Marta, 2020). Sebuah studi kasus penelitian bertujuan untuk menguji pertanyaan dan masalah penelitian, yang tidak dapat dipisahkan antara fenomena dan konteks di mana fenomena tersebut terjadi (Prihatsanti et al., 2018).

\section{Hasil dan Pembahasan}

Berdasarkan hasil studi kasus terhadap fenomena-fenomena dari Vaseline dapat diketahui bahwa penelitian ini memiliki hasil yang objektif dan subjektif. Hasil dan pembahasan mempunyai sifat objektif dan subjektif. Kualitas dalam strategi komunikasi pemasaran dibutuhkan agar memiliki strategi pemasaran yang efektif dan kuat. Kegiatan yang dilakukan oleh Vaseline berdampak positif terhadap citra Vaseline. Masyarakat menyambut dan mendukung Vaseline dalam kegiatan-kegiatannya. Sehingga Vaseline semakin dikenal oleh masyarakat dan memiliki hubungan baik antara stakeholder. Penelitian ini meninjau penerapan Filosofi Dwi Sapta Vaseline dalam orkestrasi pemasarannya. Dan juga pembahasan ini dibagi menjadi tujuh dimensi orkestrasi, yaitu satu dirijen, harmonisasi, tematik, berirama, spesifik, keterpaduan dan apresiasi.

Satu dirijen yang berarti satu nada komando dan tujuan bersama. Tidak ada pemimpin kembar dalam sebuah orkestra. Demikian juga seharusnya dalam kampanye IMC yang menggunakan satu tujuan bersama, yang mempunyai satu visi misi demi melancarkan agar tercapainya tujuan bersama. Dengan satu komando, kegiatan pemasaran dapat berjalan dengan lancar sehingga membawa dampak positif bagi perusahaan. 


\section{Jurnal Komunikasi Nusantara}

\section{E-ISSN. 2685-7650}

Vol. 2 No. 1 (2020), pp 28-41

DOI: https://doi.org/10.33366/jkn.v2i1.38

Vaseline berfokus pada memeperbaiki dan merawat kulit terutama kulit kering. Dalam kampanye, Vaseline mempunyai beberapa produk yang sangat terkenal dan banyak diketahui oleh khayalak luas. Produk- produk tersebut yaitu Vaseline body lotion, Vaseline Men Face Wash, Vaseline Super Food Serum, dan Vaseline Petroleum Jelly. Dimana mana dari semua jenis memiliki khasiat yang berbeda namun tujuannya adalah melembabkan kulit dan menghaluskan kulit. Vaseline dalam menyampaikan atau mempromosikannya melalui iklaniklan yang ada di televisi, akun-akun sosial media, website juga secara sales promotion dimana sales membagikan atau menawarkan produk Vaseline kepada target marketnya.

Vaseline telah menerapkan filosfi "Do the Best for Client", dimana Vaseline secara konsisten memproduksi semua produknya dengan kualitas terbaiknya. Produk-produk Vaseline seperti Repairing Jelly, Lip Therapy dan juga Superfood Serum disambut antusias oleh konsumennya terutama Lip Therapy karena kandungan di dalamnya terdapat repairing jelly yang mampu menjaga kelembaban bibir sepanjang waktu. Serta Superfood Serum, yang memiliki aroma berbeda dari Vaseline Body Lotion.

Tabel 1. Jenis-jenis Produk Vaseline

\begin{tabular}{|c|c|c|}
\hline Kategori & Varian & Manfaat \\
\hline $\begin{array}{l}\text { Repairing } \\
\text { Jelly }\end{array}$ & Vaseline Petroleum Jelly & $\begin{array}{l}\text { Melembabkan kulit, mengatasi kaki pecah-pecah, } \\
\text { mengatasi rambut bercabang, mengurangi rasa gatal }\end{array}$ \\
\hline \multirow{4}{*}{ Body Lotion } & Vaeline Intensive Care & $\begin{array}{l}\text { Memberikan kelembaban untuk membantu } \\
\text { memperbaiki kulit kering sehingga tampak bercahaya } \\
\text { secara alami. }\end{array}$ \\
\hline & Vaseline Healthy White & Kulit lebih cerah tanpa rasa lengket \\
\hline & $\begin{array}{l}\text { Vaseline Superfood Skin } \\
\text { Serum }\end{array}$ & $\begin{array}{l}\text { Skin serum untuk kulit terasa sehat dan glowing } \\
\text { dengan kebaikan superfood }\end{array}$ \\
\hline & Vaseline Healthy Sunblock & Kulit tampak sehat dan terlindungi dari sinar matahari \\
\hline \multirow[t]{3}{*}{ Sun Protection } & $\begin{array}{l}\text { Vaseline Healthy White Sun } \\
\text { Protection }\end{array}$ & Melindungi kulit cerahmu dari matahari dan polusi \\
\hline & $\begin{array}{l}\text { Vaseline Men Active Bright } \\
\text { Oil Expert Gel Wash } \\
\text { Vaseline Men Face Oil } \\
\text { Control Face Wash }\end{array}$ & $\begin{array}{l}\text { Bekerja seketika pada minyak yang tampak, tidak } \\
\text { membuat kulit menjadi terlalu kering } \\
\text { Menghilangkan minyak dari dalam pori-pori agar kulit } \\
\text { lebih cerah dengan sensasi sejuk }\end{array}$ \\
\hline & $\begin{array}{l}\text { Vaseline Men Face Anti- } \\
\text { dullness Face Scrub }\end{array}$ & $\begin{array}{l}\text { Butir-butir mikronya membersihkan kulit kusam dan } \\
\text { mengangkat sel kulit mati agar kulit tampak lebih } \\
\text { cerah. }\end{array}$ \\
\hline \multirow{5}{*}{ Face Wash } & $\begin{array}{l}\text { Vaseline Men Active Bright } \\
\text { Acne Expert Gel Wash }\end{array}$ & $\begin{array}{l}\text { Mengurangi bakteri penyebab jerawat, tidak membuat } \\
\text { kulit menjadi terlalu kering }\end{array}$ \\
\hline & $\begin{array}{l}\text { Vaseline Men Face Healthy } \\
\text { White Face Wash }\end{array}$ & Kulit yang tampak cerah dan sehat \\
\hline & $\begin{array}{l}\text { Vaseline Men Face Anti- } \\
\text { acne Face Wash }\end{array}$ & $\begin{array}{l}\text { Wajah tampak lebih cerah seketika }+7 \text { solusi wajah } \\
\text { berjerawat }\end{array}$ \\
\hline & & Original (for moisturised \& healthier lips) \\
\hline & Vaseline Lip Therapy Stick & $\begin{array}{l}\text { Rosy Lips (for gorgeous \& dewy lips) } \\
\text { Aloe Vera (for soothed \& hydrated lips) }\end{array}$ \\
\hline \multirow[t]{2}{*}{ Lip Therapy } & & Cocoa Butter (for smooth \& nourished lips) \\
\hline & Vaseline Lip Therapy Jar & $\begin{array}{l}\text { Rosy Lips (for soft pink lips) } \\
\text { Crème Brulee (for deliciously kissable lips). }\end{array}$ \\
\hline
\end{tabular}

Sumber: Vaseline dan Beauty Journal by Sociolla 


\section{Jurnal Komunikasi Nusantara}

\section{E-ISSN. 2685-7650}

Vol. 2 No. 1 (2020), pp 28-41

DOI: https://doi.org/10.33366/jkn.v2i1.38

Harmonisasi mengacu pada kesatuan dan keselarasan nada dan irama. Dalam kampanye pemasaran atau PR, idealnya tercipta simponi antara komunikasi korporat dan promosi produk, minimal dalam tujuan, strategi, kemasan pesan dan keterkaitan media yang digunakan. Ketika kita sudah mempunyai keselarasan maka dapat menjadi acuan komunikasi bagi koorporat dengan pihak luar agar tidak adanya kesalahpahaman.

Dalam kampanye IMC yang dilakukan oleh Vaseline ini adalah "Vaseline Healing Project" kampanye ini diadakan dengan tujuan agar memperbaiki kulit dan kualitas hidup masyarakat yang membutuhkan di seluruh dunia. Kegiatan ini diawali pada tahun 2015, ditemukan bahwa Vaseline Repairing Jelly dibutuhkan untuk mengobati permasalahan kulit di kamp-kamp pengungsian. Sejak saat itu, Vaseline dan Direct Relief menyelengggarakan "Vaseline Healing Project" dengan menyediakan obat-obatan dan Vaseline Repairing Jelly kepada orang-orang yang kurang mampu dan sedang terkena krisis atau bencana secara kontinyu. Vaseline mempunyai tujuan untuk mendorong dan menginspirasi masyarakat

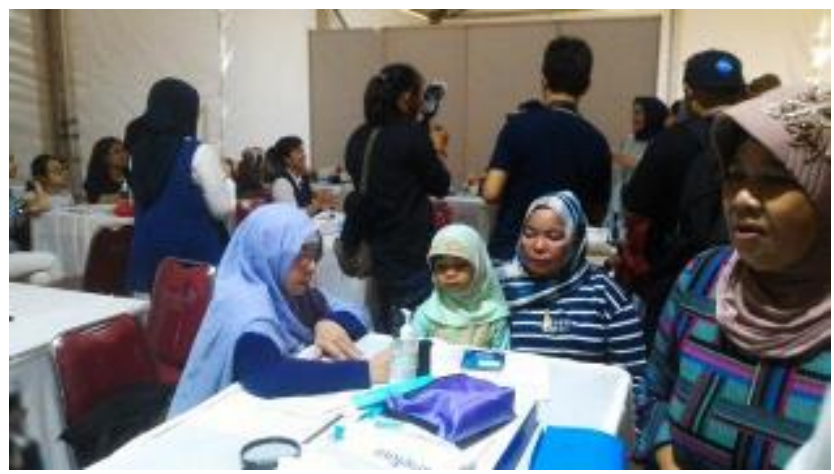

Indonesia untuk lebih peduli kepada kesehatan kulit dan percaya bahwa kulit yang sehat dapat dimiliki oleh semua orang tanpa terkecuali.

Gambar 1. "Vaseline Healing Project" di Penjaringan, Jakarta Utara

Sumber : Tribunnews

https://jakarta.tribunnews.com/2019/05/15/warga-rusun-waduk-pluit-diberi-edukasi-mengenai-

\section{kebersihan-kulit}

Vaseline mengadakan program "Vaseline Healing Project" di Rumah Susun Waduk Pluit bersama dengan Perhimpunan Dokter Spesialis Kulit dan Kelamin Indonesia (PERDOSKI) dikarenakan wilayah tersebut merupakan pemukiman yang padat dengan tingkat kebersihan yang rendah. Selain itu, PERDOSKI juga memberikan edukasi mengenai kesehatan kulit kepada masyarakat dan masyarakat juga mendapatkan Vaseline Petroleum Jelly dan obat-obatan lainnya.

Tematik dalam musik orkestra mengandung unsur-unsur musik yang berbeda namun dengan tujuan yang sama untuk tetap menghasilkan musik yang sangat mengagumkan. Hal itu sama pula dengan kampanye IMC, dimana kampanye IMC biasanya menyesuaikan dengan tema-tema tertentu namun untuk menyampaikan suatu pesan yang berkesan. Tema-tema tersebut akan berganti dengan tema-tema lainnya pada periode berikutnya. Kampanye IMC dibuat dengan berdasarkan tema tertentu. Tema inilah yang membuat kampanye IMC berfokus pada satu tujuan yang terarah.

Pada kampanye IMC yang dilakukan oleh Vaseline, tentunya telah ditentukan sebuah tema yang sesuai dengan manfaat dan guna dari produk Vaseline itu sendiri. Vaseline sebagai produk kesehatan kulit yang unggul berusaha untuk menginspirasi masyarakat untuk selalu menjaga kesehatan kulit. Tidak hanya untuk masyarakat kelas tertentu namun ditujukan untuk 


\section{Jurnal Komunikasi Nusantara}

\section{E-ISSN. 2685-7650}

Vol. 2 No. 1 (2020), pp 28-41

DOI: https://doi.org/10.33366/jkn.v2i1.38

semua golongan. Program ini terdiri dari tiga pilar utama, yaitu: (1) Menyumbangkan lebih dari satu juta produk Vaseline Repairing Jelly melalui klinik dan rumah sakit jaringan mitra Direct Relief di seluruh dunia, (2) Memberikan pelatihan mengenai kesehatan kulit bagi tenaga kesehatan, dan (3) Melaksanakan misi untuk memperbaiki kondisi kulit masyarakat yang tinggal di daerah-daerah yang paling membutuhkan. Mengingat adanya bencana alam yang terjadi di Indonesia, maka pada 2018 silam, penyelenggaraan perdana "Vaseline Healing Project" pertama kalinya di Indonesia sukses digelar di Kabupaten Bangkalan, Madura. Kabupaten Bangkalan dipilih karena permasalahan utama di daerah tersebut adalah penyakit kulit. Kebanyakan kasus tersebut disebabkan oleh factor lingkungan seperti kurangnya air bersih, ventilasi rumah yang kurang memadai, serta pencahayaan kelembaban rumah yang kurang memenuhi syarat.

Selanjutnya, Vaseline menggelar kampanyenya di wilayah bencana alam yang terjadi di wilayah Desa Batukarang yaitu erupsi gunung Sinabung yang telah mengakibatkan berbagai permasalahan kesehatan, seperti Infeksi Saluran Pernapasan Atas, diare, dan beragam masalah kesehatan kulit yang tentunya makin memperburuk produktivitas dan kualitas hidup masyarakat

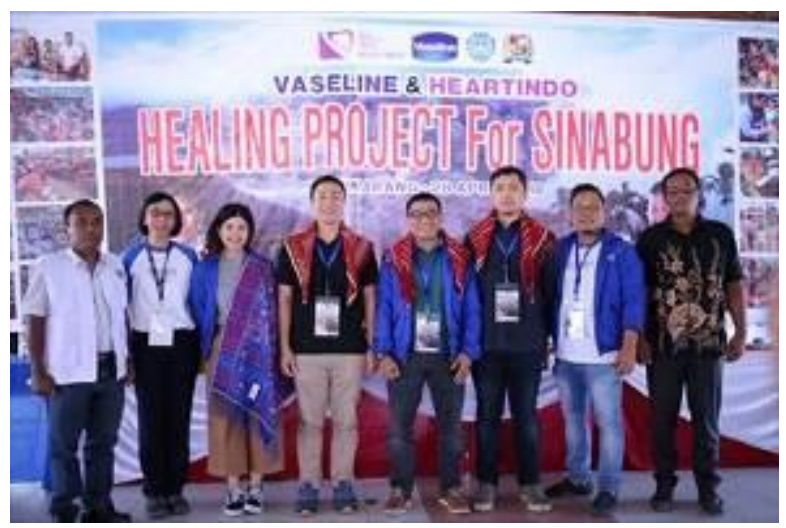

setempat. Maka program ini dilakukan untuk dapat membantu masyarakat yang membutuhkan untuk menikmati hidup yang lebih berkualitas dengan kulit yang sehat.

\section{Gambar 2. "Vaseline Healing Project" di Desa Batukarang Sumber : Unilever} https://www.unilever.co.id/news/press-releases/2018/the-vaseline-healing-project-sinabung.html

Dengan adanya kampanye IMC oleh Vaseline yang disertai dengan liputan media dan adanya publikasi di media tentunya dapat menjangkau khalayak yang luas. Kampanye IMC Vaseline ini tentunya akan menjangkau masyarakat Indonesia dari semua golongan serta menginspirasi banyak orang dan juga memberikan informasi mengenai pentingnya menjaga kesehatan kulit dan tentunya menumbuhkan rasa simpati pada masyarakat yang tertimpa bencana.

Berirama pada musik di orkestra dapat kita nikmati karna iramanya yang beraturan namun tidaklah monoton. Terkadang melambat, terkadang agak sedikit cepat, membentuk rangkaian musik yang sesuai dengan ritme yang tepat dengan tujuan menghasilkan alunan musik yang indah. Hal ini tentu menyerupai apa yang dilakukan oleh perusahaan atau organisasi dalam kampanye IMC. 


\section{Jurnal Komunikasi Nusantara}

E-ISSN. 2685-7650

Vol. 2 No. 1 (2020), pp 28-41

DOI: https://doi.org/10.33366/jkn.v2i1.38

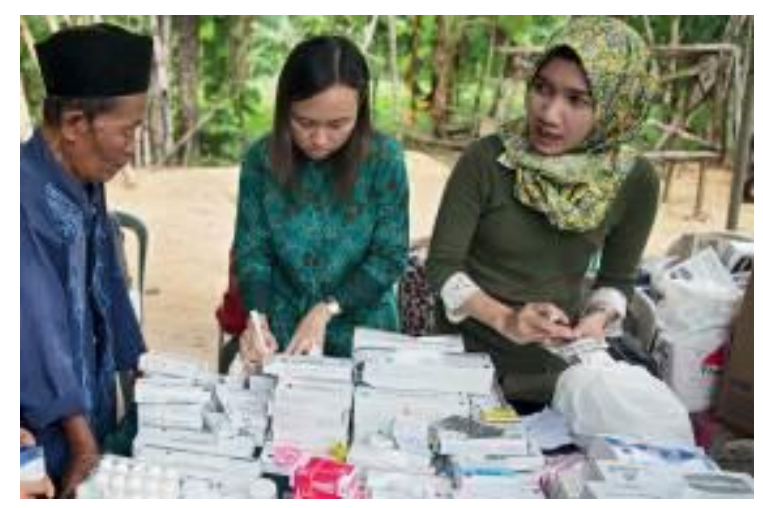

Gambar 3. "Vaseline Healing Project" membagikan obat-obatan di Jawa Timur Sumber: Mindfood https://www.mindfood.com/article/vaseline-healing-project/

IMC yang dilakukan oleh pihak perusahaan atau organisasi tidak semata-mata untuk satu hal saja namun selain untuk membangun citra tentunya untuk menaikkan tingkat penjualan produk itu sendiri. Kampanye IMC yang dilakukan oleh Vaseline pada tahun 2018 yaitu dengan menyelenggarakan "Vaseline Healing Project" dan disusul tahun-tahun berikutnya. Program "Vaseline Healing Project" menyediakan Vaseline Repairing Jelly dan obat-obatan lainnya kepada orang-orang di daerah kurang mampu atau terkena krisis dan bencana di seluruh belahan dunia, termasuk Indonesia. Kampanye Vaseline terkait dengan aspek berirama dimana kampanye Vaseline ini dapat membangun citra positif pada Vaseline mengenai bentuk bantuan Vaseline terhadap pusat-pusat kesehatan seperti puskesmas, dan juga meningkatkan brand awareness pada masyarakat mengenai produk Vaseline ini. Dengan adanya bantuan tersebut, masyarakat dapat lebih mudah menjangkau produk Vaseline dan secara langsung merasakan khasiatnya pada kulit mereka, sehingga hal inilah yang menimbulkan brand awareness pada masyarakat. Vaseline yang mungkin biasanya hanya dapat digunakan oleh golongan menengah namun juga dapat bermanfaat dan membantu golongan kebawah. Sehingga dengan adanya publikasi yang dilakukan oleh media massa, program yang diadakan oleh Vaseline ini dapat tersampaikan ke berbagai golongan masyarakat diseluruh Indonesia.

Spesifik mengartikan enggemar orkestra memang berasal dari kalangan tertentu dan sangat beragam, begitu juga dengan khalayak yang ingin dijadikan sebagai segmentasi oleh sebuah perusahaan. Penentuan segmentasi dalam memasarkan sebuah produk, maka perusahaan dalam melihat dari berbagai sisi kebudayaan masyarakat, seperti gaya hidup, motivasi dalam membeli sesuatu, maupun perbedaan yang ada dalam sekelompok masyarakat.

Vaseline, salah satu merek perawatan kulit yang sudah berdiri kurang lebih selama 140 tahun, sejak tahun 1870 oleh Robert Chesebrough. Vaseline dengan beragam produk yang dipercaya dapat memperbaiki kulit kering secara maksimal, dan dapat melindungi kulit dari paparan sinar matahari langsung. Selain body lotion, Vaseline juga menyediakan produk yang diciptakan khusus untuk menjaga kelembapan bibir kita, yaitu lip therapy. Semua produk Vaseline memiliki beragam varian dari jenis produknya masing-masing, dan semua memiliki aroma khusus yang memang diciptakan berbeda dari produk lainnya. 


\section{Jurnal Komunikasi Nusantara}

E-ISSN. 2685-7650

Vol. 2 No. 1 (2020), pp 28-41

DOI: https://doi.org/10.33366/jkn.v2i1.38

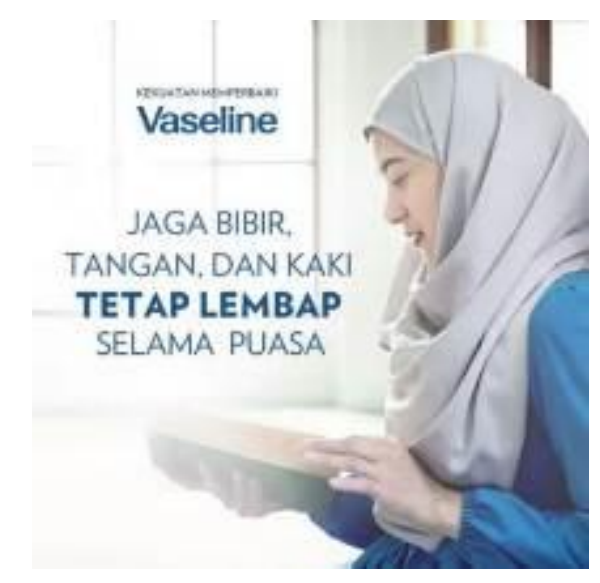

Gambar 4. Iklan Vaseline edisi Ramadhan di Instagram

Sumber: Instagram

https://www.instagram.com/p/BxYy68GnT-M/

Vaseline diciptakan untuk semua wilayah yang ada di Indonesia, dan semua kalangan, baik laki-laki maupun perempuan. Tetapi, segmen khalayak yang menjadi fokus utama dari produk ini adalah kaum wanita yang memiliki masalah dengan kulit kering. Karena Vaseline memiliki segmentasi khalayak secara spesifik yaitu kaum wanita. Maka pada pemilihan bintang iklan pada produk Vaseline juga menggunakan seorang wanita. Setiap iklan yang ditampilkan selalu menggunakan seorang wanita yang menggunakan hijab, dengan tujuan untuk menyampaikan kepada masyarakat bahwa produk Vaseline halal dan cocok digunakan oleh semua kalangan masyarakat. Iklan dari produk Vaseline adalah Vaseline Repairing Jelly yang menunjukkan seorang wanita berada di luar ruangan dan membutuhkan kelembapan pada bibir, maupun tumit kakinya. Pada iklan, ditampilkan Vaseline mengajarkan kita hal kecil yang mungkin sering kita abaikan, yaitu selain menjaga kelembapan kulit badan, kita juga perlu memperhatikan kelembapan bibir kita. Karena tanpa kita sadari bahwa paparan sinar matahari juga dapat menjadi salah satu penyebab bibir kita menjadi kering dan pecah-pecah. Oleh sebab itu penggunaan pelembab bibir menjadi salah satu cara kita mencegah terjadinya bibir kering dan pecah-pecah.

Keterpaduan antara setiap anggota orkestra dalam orkestra musik akan menciptakan irama yang menarik dan menghasilkan penampilan yang baik. Di dalam IMC, bila menyatukan kreatifitas dalam program yang dijalankan akan terjadi Sinergi komunikasi pemasaran yang kuat. Vaseline menginspirasi masyarakat untuk lebih peduli terhadap kesehatan kulit karena menjaga kesehatan kulit tidak hanya bagi kita yang ingin merawat demi kecantikan tetapi juga kesehatan tubuh secara menyeluruh.

Vaseline mempromosikan dua jenis produk secara bergantian, produk yang dipromosikan tersebut merupakan dua jenis produk yang berbeda. Vaseline Repairing Jelly yang multifungsi untuk melembabkan kulit, mengatasi bibir kering, mengatasi kaki pecah-pecah, pembersih make up, mengatasi masalah rambut. Iklan tersebut memuat produk repairing jelly dengan varian terbaru yaitu lip therapy. Lip therapy tersebut memiliki 2 jenis packaging yaitu jar dan juga stick dengan beberapa varian dan mampu melembabkan bibir sepanjang hari. Kemudian, body lotion Vaseline yang terbaru yaitu Superfood Serum dengan aroma yang berbeda dari body lotion sebelumnya. 


\section{Jurnal Komunikasi Nusantara}

\section{E-ISSN. 2685-7650}

Vol. 2 No. 1 (2020), pp 28-41

DOI: https://doi.org/10.33366/jkn.v2i1.38

Sesuai dengan prinsip Vaseline yaitu meningkatkan kesadaran serta memberikan edukasi betapa pentingnya merawat kesehatan kulit, membangkitkan kepercayaan diri, meningkatkan dan menjaga kualitas hidup masyarakat. Maka dari itu Vaseline mengutamakan kebutuhan kesehatan tubuh dan kulit konsumennya. Melalui iklan yang di tampilkan dari berbagai produk Vaseline, diharapkan konsumen dapat memahami inovasi produk yang dilakukan oleh Vaseline. Terlebih lagi inovasi tersebut merupakan upaya dari Vaseline untuk menjaga konsistensi dan memenuhi kebutuhan konsumennya.

Bentuk apresiasi dalam pergelaran orkestra adalah bentuk ucapan terima kasih konduktor orkestra kepada penonton dan tepuk tangan yang meriah dan sahutan dari penonton kepada anggota orkestra yang telah membawakan penampilan dengan baik. Menurut Filosofi Dwi Sapta dijelaskan bahwa "Do the Best for Our People", dimana perusahaan harus memberikan yang terbaik kepada pihak internal maupun eksternal. Hal ini diterapkan oleh Vaseline, yaitu memberikan rewards sebagai bentuk apresiasi terhadap loyalitas dari konsumennya.

Vaseline mengadakan event "Vaseline Men Nobar Maksimal-Bringing Brazil to You" yang ditujukan pada konsumen setia Vaseline Men dengan membawa 10 orang konsumen Vaseline Men yang beruntung untuk menyaksikan Piala Dunia 2014 secara langsung di Brazil. Hanya dengan mengumpulkan kode unik yang terdapat di produk Vaseline Men Face Wash ataupun Vaseline Men Face Moisturizer dan 10 orang dengan poin terbanyak akan mendapatkan tiket menyaksikan Piala Dunia di Brazil tanpa diundi.

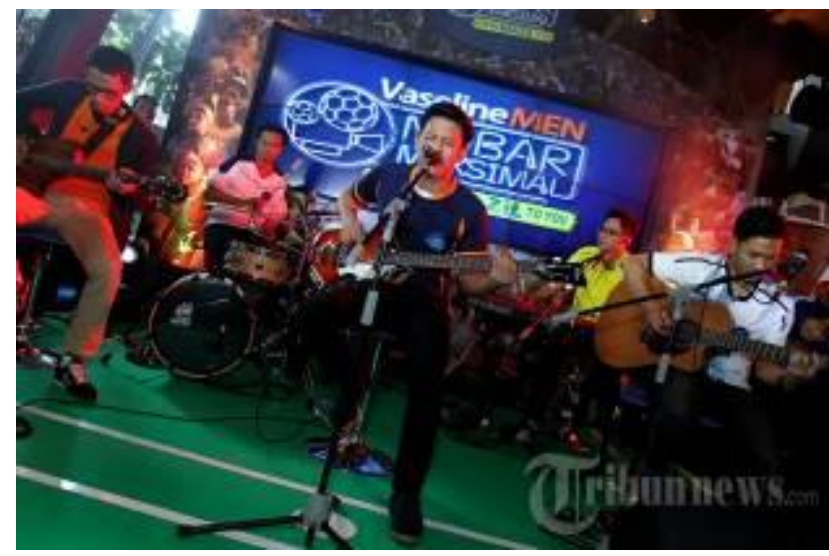

Gambar 5. Vaseline Men Nobar Piala Dunia 2014

Sumber : Tribunnews

https://www.tribunnews.com/images/seleb/view/1130662/aksi-noah-di-vaseline-men-nobar$\underline{\text { maksimal }}$

Selain itu, Vaseline juga memberikan rewards berupa kesempatan pergi Umroh dengan mengupload struk pembelian Vaseline Repairing Jelly ukuran $50 \mathrm{ml}$ dan $100 \mathrm{ml}$ ke web.Pomona.id dan setiap sturk pembelian yang lolos verifikasi akan mendapat satu kupon. Promo ini berlaku di semua outlet Guardian dan untuk memenangkan hadiah Umroh, konsumen perlu mengumpulkan kupon sebanyak-banyaknya. 


\section{Jurnal Komunikasi Nusantara}

E-ISSN. 2685-7650

Vol. 2 No. 1 (2020), pp 28-41

DOI: https://doi.org/10.33366/jkn.v2i1.38

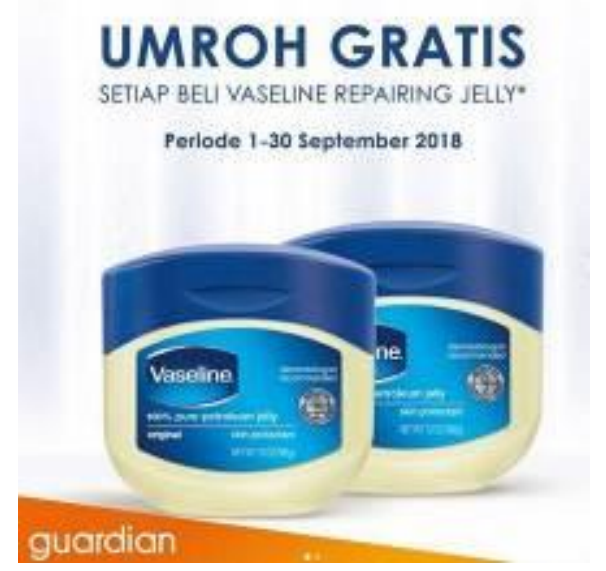

Gambar 6. Poster Promo Vaseline

Sumber : Gotomalls

https://www.gotomalls.com/promotions/LslvDst5IL-RAEQk/umrah-gratis-dari-vaseline-di-guardian

\section{Kesimpulan}

Integrated Marketing Communication (IMC) melakukan komunikasi brand yang sesuai dengan konsumen serta memberikan pengalaman yang baik terhadap konsumen dalam segala aspek. IMC berusaha menyampaikan pesan secara positif terhadap konsumen sehingga meninggalkan kesan baik pada benak konsumen. Maka dari itu Vaseline melakukan penerapan Filosofi Dwi Sapta yang ditinjau dari terminologi Orchestration dalam menjalankan setiap kegiatan pemasarannya. Vaseline sangat memperhatikan kesehatan kulit dan percaya bahwa Vaseline mampu membantu memperbaiki kulit agar sehat kembali. Dengan adanya pesan yang kuat dan konsisten dari Vaseline mengenai pentingnya untuk menjaga kesehatan kulit, menjadi kunci penting bagi eksistensi brand Vaseline itu sendiri.

Vaseline tidak hanya menjual produk untuk kulit, sebagai skin expert, tetapi memiliki tujuan untuk mengajak orang-orang untuk lebih memperhatikan dan merawat kesehatan kulit agar terhindar dari kerusakan kulit. Vaseline pada kampanye IMC mengadakan event yang bertujuan untuk mengedukasi masyarakat, tidak hanya golongan tertentu tapi mencakup semua golongan untuk menjaga kesehatan kulit masing-masing. Hal ini selaras dengan terciptanya pengalaman baik yang dirasakan oleh masyarakat mengenai Vaseline. Membangun persepsi positif dan citra baik Vaseline di mata masyarakat. Selain itu, Vaseline turut serta membantu korban bencana alam yang terjadi di Indonesia melalui Vaseline Healing Project dengan menyediakan Vaseline Repairing Jelly dan obat-obatan di pusat-pusat kesehatan serta menjalin kerjasama dengan petugas-petugas kesehatan untuk membantu memperbaiki kondisi kulit para korban bencana. Hal ini bukan sekedar wacana melainkan tindakan nyata yang dilakukan oleh Vaseline.

Berkaitan pula dengan Filosofi Dwi Sapta yang memiliki inti untuk melakukan yang terbaik bagi semua pihak. Vaseline mewujudkannya dengan berpegang pada tujuan dari brand itu sendiri yaitu secara konsisten untuk selalu menjaga kesehatan kulit masyarakat dengan meproduksi produk-produk berkualitas tinggi namun tetap dapat dijangkau oleh semua kalangan. Program-program yang dilakukan oleh Vaseline selaras dengan dampak positif yang diberikan pada masyarakat luas. Vaseline menjaga reputasinya sebagai produk kesehatan kulit yang berkualitas dan bermanfaat bagi kulit. Kepuasan konsumen terhadap suatu brand sangatlah berperan penting dalam keberlangsungan suatu brand. Keberadaan Vaseline hingga saat ini tentunya karna keselarasan dalam segala aspek pemasaran serta nilai yang diberikan Vaseline terhadap masyarakat luas. 


\section{Jurnal Komunikasi Nusantara}

E-ISSN. 2685-7650

Vol. 2 No. 1 (2020), pp 28-41

DOI: https://doi.org/10.33366/jkn.v2i1.38

\section{Acknowledgment}

Terima kasih kepada rekan satu tim, yaitu Catherine, Destyana Wahyu Mulyadi dan Nyken Ayu Phinesa serta Jurnal Komunikasi Nusantara (JKN) yang diterbitkan oleh Unitri Press, Program Studi Ilmu Komunikasi Universitas Tribhuwana Tunggadewi.

\section{Daftar Pustaka}

A. Adji Watono, M. C. W. (2011). IMC (Integrated Marketing Communication) That Sells. PT GRAMEDIA PUSTAKA

UTAMA. https://books.google.co.id/books?id=4ihRDwAAQBAJ\&pg=PR31\&lpg=PR31\&dq=the+ philosophy + of + dwi + sapta\&source $=$ bl\&ots $=$ tmymbDgjQX\&sig $=$ ACfU3U2GcIauq58jLU 8Jh86_CvDKnNzZOg\&hl=id\&sa=X\&ved=2ahUKEwjD8YCl48noAhUa6nMBHbkOCwQ6AEwAXoECAsQLw\#v=onepage \&q=the philosophy of $\mathrm{d}$

Catherine, Mulyadi, D. W., \& Phinesa, N. A. (2020). Logika Orkestrasi Pada Rangkaian Komunikasi Pemasaran Logic of Orcestration on Integrated Marketing Communication Concatenation Through Lifebuoy', S Healthy Sharing. MEDIALOG: Jurnal Ilmu Komunikasi, III(I), 120-138. $\quad$ http://www.jurnalumbuton.ac.id/index.php/Medialog/article/download/547/427/

Estaswara, B. H. (2008). Think IMC! PT Gramedia Pustaka Utama. https://books.google.co.id/books?id=-

FRJDwAAQBAJ\&pg=PA158\&lpg=PA158\&dq=3+dasar+kerangka+imc\&source=bl\&ot $\mathrm{s}=\mathrm{eMuU} 3 \_\mathrm{TWxL} \& s i g=\mathrm{ACfU} 3 \mathrm{U} 2 \mathrm{Fpb} 5 \mathrm{R} 17 \mathrm{xB}-\mathrm{e}-$

wzx9LtK1imkzZtw\&hl=id\&sa=X\&ved=2ahUKEwjnmqXPkdPoAhWNbSsKHWIsA6M Q6AEwDnoECAwQLA\#v=onepage $\& \mathrm{q}=3$ dasar kerangka imc \& $\mathrm{f}=\mathrm{f}$

Fensi, F., \& Christian, M. (2018). Determinan Citra Merek Pada Iklan Produk Gawai "Vivo" Berdasarkan Aspek "Celebrity Endorser." Bricolage : Jurnal Magister Ilmu Komunikasi, 4(02), 163. https://doi.org/10.30813/bricolage.v4i02.1659

Garnis, A. (2019). Warga Rusun Waduk Pluit Diberi Edukasi Mengenai Kebersihan Kulit. Tribunnews. https://jakarta.tribunnews.com/2019/05/15/warga-rusun-waduk-pluit-diberiedukasi-mengenai-kebersihan-kulit

Gotomalls. (2018). Free Umrah from Vaseline at Guardian September 2018. Gotomalls. https://www.gotomalls.com/promotions/LslvDst5IL-RAEQk/umrah-gratis-dari-vaselinedi-guardian

Hardhiyanti, Y., \& Rasyid, U. N. (2017). Komunikasi Bisnis Berbasis Etika Lingkungan Sebagai Csr the Body Shop Indonesia. Bricolage: Jurnal Magister Ilmu Komunikasi, 3(2), 103-117. https://doi.org/10.30813/bricolage.v3i02.925

Mahayoni. (2015). Menata Komunikasi Pada Media Sosial Online Untukmenghindari Jerat Hukum. Bricolage: Jurnal Magister Ilmu Komunikasi, 1(2). https://doi.org/10.1017/CBO9781107415324.004

Nurhadi, Z. F. (2015). Teori Teori Komunikasi dalam Perspektif Kualitatif. Ghalia Indonesia.

Prasetya, A. A., Saputra, J. K., \& Stevani. (2020). Campaign for the Real Beauty Shampoo Dove Ditinjau Dari Terminologi Pemasaran 360 Derajat. Jurnal Lensa Mutiara Komunikasi, 3 , 15-35. mutiara.ac.id/index.php/JLMI/article/download/1072/923/

Prihatsanti, U., Suryanto, S., \& Hendriani, W. (2018). Menggunakan Studi Kasus sebagai Metode Ilmiah dalam Psikologi. Buletin Psikologi, 26(2), 126. https://doi.org/10.22146/buletinpsikologi.38895

Rambu Babang, R., \& Rachmad Rinata, A. (2019). Strategi Komunikasi Pemasaran Sentra Tenun Prailiu dalam Meningkatkan Penjualan Kain Tenun Sumba Timur. Jurnal 


\section{Jurnal Komunikasi Nusantara}

E-ISSN. 2685-7650

Vol. 2 No. 1 (2020), pp 28-41

DOI: https://doi.org/10.33366/jkn.v2i1.38

Komunikasi Nusantara, 1(2), 78-85. https://doi.org/10.33366/jkn.v1i2.24

Sampurna, A., Tandian, M., Huang, V., Florescia, R., \& Marta, R. F. (2020). Implementasi Total Branding Dalam Perspektif Semiotika Pemasaran. Jurnal Universitas Pancasila, 10(2). https://doi.org/https://doi.org/10.35814/coverage.v10i2.1384

Sapoetri, A., \& Pannindriya, T. (2019). Geliat Interaksi Sosial Dokter Masa Kini Melalui Media Sosial Instagram. Bricolage : Jurnal Magister Ilmu Komunikasi: Jurnal Magister Ilmu Komunikasi, $5(2)$,

121-140. https://journal.ubm.ac.id/index.php/bricolage/article/view/1884

Saputra, N., \& Marta, R. F. (2020). Optimalisasi Model Strategi Public Relations Museum Penerangan dalam Membentuk Citra Publik. Calathu: Jurnal Ilmu Komunikasi, 2(1), 20-31.

Smith, K. T. (2003). The Marketing Mix Of Imc: A Move from The 4 P's to The 4C'S. 2-7.

Tarsani. (2016). Strategi Komunikasi Pemasaran Dompet Dhuafa dalam Meningkatkan Kepercayaan Muzakki. Bricolage: Jurnal Magister Ilmu Komunikasi, 2(1), 56-70.

Teguh, M., \& Ciawati, S. T. (2020). Perancangan Strategi Digital Marketing Communication Bagi Industri Perhotelan Dalam Menjawab Tantangan Era Posmoderen Design of Digital Marketing Communication Strategy for the Hospitality Industry to Answer the Postmodern Era Challenges. Bricolage : Jurnal Magister Ilmu Komunikasi, 6(1), 51-64.

Tovia, J. (2018). Mengangkat Kutukan: Proyek Penyembuhan Vaseline. Mindfood. https://www.mindfood.com/article/vaseline-healing-project/

Tribunnews. (2014). Aksi NOAH di Vaseline Men Nobar Maksimal. Tribunnews. https://www.tribunnews.com/images/seleb/view/1130662/aksi-noah-di-vaseline-mennobar-maksimal

Turnbull, C. F. and S. (2019). Marketing Communications: Touchpoints, Sharing and Distruption (8th ed.). Pearson Education Limited. https://books.google.co.id/books?id=6oyfDwAAQBAJ\&pg=PT551\&lpg=PT551\&dq=im c+orchestration+terminology\&source=bl\&ots=O6OMSYkHPV\&sig=ACfU3U1VCoFQf CF6nhev0lc0Om3yTg0K4g\&hl=id\&sa=X\&ved=2ahUKEwiZnpCt_7zoAhWPeX0KHel NCjwQ6AEwDnoECAgQAQ\#v=onepage \&q=orchestration\&f

Ulfa, R., \& Marta, R. F. (2016). Implementasi Komunikasi Pemasaran Terpadu Pada Yayasan Nurul Ibad Jakarta Timur. Bricolage: Jurnal Magister Ilmu Komunikasi, 2(2), 71-81.

Unilever. (2020a). Tentang Kami. Unilever Indonesia. https://www.unilever.co.id/about/

Unilever. (2020b). "Vaseline Healing Project" Bantu Perbaiki Kualitas Hidup Masyarakat Pengungsi Erupsi Gunung Sinabung di Desa Batukarang. Unilever Indonesia. https://www.unilever.co.id/news/press-releases/2018/the-vaseline-healing-projectsinabung.html

Vaseline. (2019). Kekuatan Memperbaiki : Vaseline. Instagram. https://www.instagram.com/p/BxYy68GnT-M/

Vaseline. (2020). Siapa Kami. Vaseline. vaseline.com/id/id

Widianti, N. (2019). Lip Therapy, Lip Care Terlaris dari Vaseline Kini Resmi Hadir di Indonesia (+Review!). Beauty Journal by Sociolla. https://journal.sociolla.com/beauty/vaseline-lip-therapy

Yulius, \& Prasetya Widodo, H. (2019). Strategi Komunikasi Pemasaran RRI Malang dalam Upaya Pencapaian PNBP dan Meningkatkan Jumlah Pengiklan. Jurnal Komunikasi Nusantara, 1(2), 60-71. https://doi.org/10.33366/jkn.v1i2.19 